\title{
Research And Development Investment
}

\author{
Nicholas J. Cannon, University of Detroit Mercy, USA \\ Gregory W. Ulferts, University of Detroit Mercy, USA \\ Terry L. Howard, University of Detroit Mercy, USA
}

\begin{abstract}
The United States has long enjoyed a leadership role in research and development investment and they invest more in both basic and applied scientific research than any other country. The U.S. preeminence in $R \& D$ investment, however, is at a critical point. U.S. R\&D investment has been declining as a percentage of the nation's GDP since 2009, and in 2013, U.S. R\&D investment is expected to decline in real dollars as well. Declining investment in $R \& D$ is the result of budgetary constraints and the lack of political consensus as to the economic value of the government's continued commitment to $R \& D$ programs. This decline in U.S. investment comes at a time when global $R \& D$ investment is increasing significantly. Economic rivals, led by China in particular, have made investment in $R \& D$ a core component of their plans for economic growth and have committed themselves to increasing and substantial $R \& D$ investment. U.S. policymakers need to take action now to reverse what could become a policy trend of decreased government investment in $R \& D$, which has both a short-term and long-term impact. R\&D spending is an "economic and employment driver" and ultimately employs 8.27 million U.S. workers, generating \$1.238 trillion dollars to the U.S. economy. In addition, government investment funds the majority of basic scientific research which, in the past, has led to such innovations as digital recording technology, communication satellites, global positioning systems (GPS), and the Internet. It is unclear if the private sector alone can make up the difference in government $R \& D$ investment. If the U.S. fails to protect its leadership position in $R \& D$ investment, it consequently risks its leadership in science, technology, productivity, and innovation which is the basis of the nation's employment and economic activity.
\end{abstract}

Keywords: R\&D; Research; Investment

\section{INTRODUCTION}

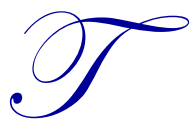

he United States has long enjoyed a leadership role in research and development investment. The U.S. is expected to invest approximately $\$ 423.7$ billion in R\&D in 2013 - more than double China, the U.S.'s closest R\&D rival. U.S. investment exceeds one-third of global R\&D spending. The U.S. R\&D investment is shared among (1) federal, state, and local government (federal \$128.8 billion; other government $\$ 4.5$ billion); (2) private industry (\$261.7 billion); (3) academia ( $\$ 12.7$ billion); and (4) non-profit organizations ( $\$ 16.0$ billion). Although private industry accounts for more than two times all U.S. R\&D investment, the federal government funds $60 \%$ of all basic scientific research.

\section{THE ISSUE}

The U.S. preeminence in R\&D investment, however, is at a critical point. Over most of the past decade, U.S. R\&D investment has grown in real terms. However, R\&D investment has been declining as a percentage of the nation's GDP since 2009. For the first time in 2013, U.S. R\&D investment is expected to decline in real dollars as well. For example, U.S. gross domestic expenditure on R\&D in 2011 was $\$ 412.4$ billion, or 2.7\% of GDP; in 2012, gross domestic expenditure on R\&D was $\$ 418.6$ billion, or $2.8 \%$ of GDP; and the projected 2013 U.S. gross domestic expenditure on R\&D - \$423.7 billion - represents $2.66 \%$ of GDP. When the 2013 figures are adjusted for an OMB estimated inflation rate of $1.9 \%$, U.S. investment in R\&D is expected to decline $0.7 \%$ in real dollars. More problematic is that federal investment in R\&D grew at a $1.3 \%$ annual rate between 1989 and 2009 at a time when GDP grew an average of $2.4 \%$ annually. Although $60 \%$ of basic scientific research is conducted in academic institutions, federal funding for R\&D is expected to decline by $0.8 \%$ in 2013. 
Declining investment in R\&D is the result of economic conditions, budgetary constraints, and the lack of political consensus as to the economic value of the government's continued commitment to R\&D programs. Private sector investment in R\&D has slowed in response to the sluggish economy and concerns about future growth prospects.

The federal government has steadily been decreasing its commitment to R\&D projects as it has addressed budget concerns overall. In addition, the Budget Control Act of 2011 (BCA) has imposed strict limits on R\&D budgets for all departments and agencies. Furthermore, any increase to R\&D budgets is complicated by the fact that the federal government currently operates under a continuing resolution (CR). Related to this, the recent sequestration has impacted the budgets of federal R\&D projects as with other federal spending.

Federal budgetary cuts to R\&D programs is at least partially in response to disagreements as to the role that government should play in funding $\mathrm{R} \& \mathrm{D}$. There is significant ideological opposition to government funding of $R \& D$ among those who would prefer that the private sector undertake all R\&D investment.

This decline in U.S. investment comes at a time when global R\&D investment is increasing significantly. Global $R \& D$ spending is projected to grow by $\$ 53.7$ billion, or $3.7 \%$, to a total $\$ 1.496$ trillion in 2013 . China's spending on R\&D represents the largest share of this increase - $\$ 22.9$ billion. China's $2013 \mathrm{R} \& \mathrm{D}$ spending reflects an $11.6 \%$ growth rate (compared to $1.2 \%$ growth in U.S. R\&D spending). In fact, double-digit annual growth has been a feature of China's R\&D spending over the past decade. Economic rivals, led by China in particular, have made investment in R\&D a core component of their plans for economic growth and have committed themselves to increasing and substantial R\&D investment.

\section{DIRECTION}

U.S. policymakers need to take action now to reverse what could become a policy trend of decreased government investment in R\&D. Government investment funds the majority of basic scientific research which has led to such innovations as digital recording technology, communication satellites, global positioning systems (GPS), and the Internet. It is unclear whether the private sector alone can or will make up the difference in government R\&D investment. Private industry often has little incentive to make large investments in research which, although the basis of economic development, does not result in direct profits and will likely be shared with its competitors. Contrary to criticisms that public investment in $R \& D$ crowds out private investment, research shows that government-funded $R \& D$ in basic research usually drives and supports private $R \& D$.

$R \& D$ investment has both short-term and long-term impacts. $R \& D$ spending is an "economic and employment driver" and the impact of R\&D expenditures alone is significant. It is projected that the $\$ 423.7$ billion in U.S. R\&D expenditures in 2013 will directly employ 2.47 million people and ultimately employ 8.27 million U.S. workers across all industries. Overall, it will generate $\$ 1.238$ trillion dollars in the U.S. economy. As non-U.S. $R \& D$ investment grows, there is the danger of $R \& D$ jobs shifting overseas with the resulting loss of the impact of domestic R\&D expenditures in the economy.

The loss of U.S. dominance in R\&D has more serious long-term implications for the U.S. economy. R\&D fuels innovation, which in turn drives the development game-changing technologies. The development of these technologies underpins growth, which in turn leads to job and wealth creation. The innovation supported by strong $\mathrm{R} \& \mathrm{D}$ programs is the key to global economic competitiveness.

\section{CONCLUSION}

If the U.S. fails to protect its leadership position in R\&D investment, it consequently risks its leadership in science, technology, productivity, and innovation, which is the basis of the nation's employment and economic activity. 


\section{AUTHOR INFORMATION}

Mr. Nicholas Cannon received his JD and MBA from the University of Detroit Mercy, and is currently completing UDM Certificate Programs in Health Services Administration Management and Finance. He is a recipient of the State Bar of Michigan's Thomas J. Trenta Health Care Law Section Academic Achievement Award and the George R. Bodurow Memorial Scholarship. He is a student member of the UDM Chapters of Alpha Sigma Nu, Alpha Iota Delta, and Beta Gamma Sigma. Mr. Cannon is an Intern with the Medicare Compliance Department of Blue Cross Blue Shield of Michigan and is a graduate assistant for the UDM College of Business Administration. E-mail: cannonnj@udmercy.edu

Dr. Gregory W. Ulferts is a Professor of Decision and Systems Sciences in the College of Business Administration at the University of Detroit Mercy. His scholarly activities have included research and publication on various topics related to management information systems, financial management, decision sciences, small business administration, and international business. Dr. Ulferts has served as a consultant in business and government in areas such as strategic and technology planning, operations and procurement management, analysis and design of systems, and business development. E-mail: ulfertgw@udmercy.edu (Corresponding author)

Mr. Terry L. Howard is a Lecturer of Decision and Systems Sciences in the College of Business Administration at the University of Detroit Mercy. He works with Business Leadership Network of Michigan and serves as the Director of the Leadership and Economic Independence program, working with individuals who have challenges. Mr. Howard has MBA/MSCIS degrees from the University of Detroit Mercy and has certification in Security Information. He is Treasurer of the International Honor Society, Alpha Iota Delta. Mr. Howard is a motivational speaker and has published papers nationally in professional and academic journals. E-mail: howardtl@udmercy.edu

\section{REFERENCES}

1. $\quad$ Battelle. (2012, December). 2013 Global $R \& D$ funding forecast. Cleveland, OH: Author.

2. $\quad$ Ezell, S. (n.d.). U.S. is falling further behind in research and development funding. Innovationfiles.org. Retrieved from http://www.innovationfiles.org/u-s-is-falling-further-behind-in-research-and-developmentfunding/

3. The Information Technology \& Innovation Foundation. (n.d.). U.S. drops to 27th in ITIF survey of global $R \& D$ tax incentives. Washington, DC: Author.

4. Leopold, G. (2012, January 20). NSA: U.S. losing ground as more R\&D jobs head overseas. EE Times.

5. $\quad$ Plumer, B. (2013, February 26). The coming R\&D crash. The Washington Post.

6. Studt, T. (n.d.) World's best $R \& D$ companies. Rdmag.com. Retrieved from http://www.rdmag.com/articles/ 2007/10/world\%E2\%80\%99s-best-r-d-companies

7. Thibodeau, P. (2012, December 24). China set to surpass U.S. in R\&D spending in 10 years. Computerworld. 


\section{NOTES}

